\title{
SYNERGY OF TECHNOLOGIES IN TEACHING MATHEMATICS
}

\section{Michal NOVÁK}

\begin{abstract}
The article gives an overview of professional mathematical software which students entering universities of technology are likely to use from the very beginning of their engineering studies. The article is intended as information for secondary school teachers who would like to make the transition between secondary school and university easier for their students. The software is discussed from the point of view of accessibility of the content rather than functionality. Differences of approach to preparing and distributing content are also discussed. Some suggestions of didactic use of respective products are also included.
\end{abstract}

Key words: ICT in teaching mathematics, Maple, Mathematica, mathematical software, MATLAB.

\section{SYNERGIE TECHNOLOGIÍ VE VÝUCE MATEMATIKY}

Resumé: Příspěvek podává přehled profesionálního matematického softwaru běžně používaného ve výuce matematiky na vysokých školách technických. Je koncipován mj. jako informace pro učitele středních škol, kteří chtějí usnadnit svým studentům přechod ze střední školy na vysokou školu technického směru. Problematika matematického softwaru je diskutována z pohledu dostupnosti jeho obsahu spíše než z pohledu funkcionality. Jsou diskutovány rozdílné př́stupy jednotlivých technologií $\mathrm{k}$ tvorbě a distribuci obsahu a uvedeny príklady využití zmiňovaných technologií ve výuce.

Klíčová slova: ICT ve výuce matematiky, Maple, matematický software, Mathematika, MATLAB

\section{Introduction}

Teaching mathematics at secondary schools has a number of different roles. Undoubtedly, one of its important aspects is to prepare students for their studies at universities of technology where mathematics (together with physics) is the theoretical background of education of prospective engineers. It is this aspect of teaching mathematics at secondary schools that is developed in the CZ.1.07/1.3.00/14.0001 Operational Program Education for Competitiveness project conducted at Department of Mathematics, Faculty of Electrical Engineering and Communication, Brno University of Technology ("project" and "FEEC BUT" further on). We believe that by presenting secondary school teachers with the way, form and means of teaching mathematical subjects taught during the first three semesters at a typical faculty of a university of technology, we give students of those teachers chances for a smoother start-up of their engineering education.

In this paper we discuss software means of teaching mathematics in the introductory university of technology courses to show how a secondary school teacher can process this information in the secondary school context in order to "make his/her students' lives easier" once they enter a university of technology. Even though this paper could be regarded as a case study of a department of mathematics at a university of technology, it can be applied to university context accordingly.

\section{Software means of teaching mathematics: a range of technologies}

A secondary school graduate entering a university of technology (regardless of specialization or location) almost immediately faces the necessity to use one of the three major mathematical software bundles: Maple (1), MATLAB (3) or Mathematica (4). Even though historically these products have different origins and had been used for different purposes (such as MATLAB for numerical computations or Maple for teaching algebra and for symbolic computations), all three technologies have converged to a state when they are almost fully interchangeable. Thus preference of one or other is mainly a personal preference of a teacher, matter of historical funding schemes at a given faculty, etc. From the point of view of a student a user - this means that he/she should be familiar with all of these technologies or rather with a way mathematical software works in general.

Within all the three software bundles (or technologies) certain layers can be identified: 
- The stand-alone product, i.e. the basic original version of the software, usually licensed as a single-user licence. The licence may be used at a designated computer or by a designated user.

- Various types of network licences of the original product. Regardless of type, the licence may be used at computers where the software has been installed and which have access to the licence manager. This might be a problem when student access from their home computers is required. Licensing scheme is the only difference between this and the previous layer - otherwise the products are identical.

- Technologies for web access such as MapleNet (1), webMathematica (6).

- Teacher-oriented tools, such as tools for test creation and test processing such as Maple T.A. (1).

- Advanced professional modelling tools such as MapleSim, Simulink (3).

- Other unsorted tools such as Wolfram Alpha.

- Third-party open source alternatives such as Octave as an alternative to MATLAB.

Each of these layers is used in a specific context and at a specific stage of education. Naturally, the advanced professional modelling tools are used in engineering master study programmes. However, the stand-alone product or the teacher oriented tools or technologies for web access might be used at any stage of education - e.g. at secondary schools.

There are two strategies a workplace can follow when considering using mathematical software: either to choose one and build its infrastructure on it or to try use all of the bundles with a special role assigned to each component or layer. The latter way was chosen by the Department of Mathematics FEEC BUT. Thus further on we shall discuss all layers of all three technologies from the point of view of a secondary school wishing to start using professional mathematical software.

\section{Stand-alone products in teaching}

Using the stand alone products in teaching is the simplest and most often followed way of using mathematical software. Many secondary schools tend to use specialized one purpose or "small" applications or freeware. This is either for financial reasons or because such software "does what is required".
If one of the Maple - MATLAB Mathematica triplet is to be considered, secondary schools might prefer using Maple or Mathematica in mathematical classes or Octave, an open source alternative to MATLAB, in specialized mathematical seminars or informatics classes. The financial reasons may cease to be a problem when some additional funding is secured as Maple or Mathematica offer reasonably priced network licensing schemes suitable for secondary schools. This enables schools e.g. to install the software on all computers used by the school on condition that a certain maximum number of licences is used at a time (Mathematica). This condition may even not be imposed (Maple, Mathematica under some schemes). For further discussion on this issue cf. also section 8 .

A great number of papers or studies have explored the issue of using the stand alone products in teaching. In fact, most papers discussing the use of ICT in mathematical education discusses the use of mathematical software as stand-alone applications installed on either teacher or student computers.

For books cf. e.g. (Vaníček, 2009) or (Žilková, 2009); for examples of introductory manuals cf. e.g. (Hlavičková, 2012), (Kolářová, 2012) or (Kovár, 2012).

\section{Technologies for web access}

There are many contexts in which the traditional way of using mathematical software is not convenient, not wanted, or even not possible. This includes situations when

- the software is to be used in a controlled way outside classes (such as for homework, home-practice or by distance students),

- using the software licence is not possible (e.g. for financial reasons),

- users prefer using third-party prepared content which is not compatible with their installed software.

Direct access is obviously the most favoured way of web access. In this mode the user cannot notice any principal difference between use of the stand-alone software installed on his/her client computer and the web interface of the software even though the interface might not look the same. However, this mode of work is not legally possible with any of the Maple - MATLAB Mathematica triplet. Only Octave (an open source alternative to MATLAB) can be installed on a server and used this way with certain limitations mostly caused by security reasons 
(thus after some access and computational restrictions). Department of Mathematics FEEC BUT offers this type of access to secondary schools participating in our project - see Fig. 1.

\section{Práce se softwarem Octave}

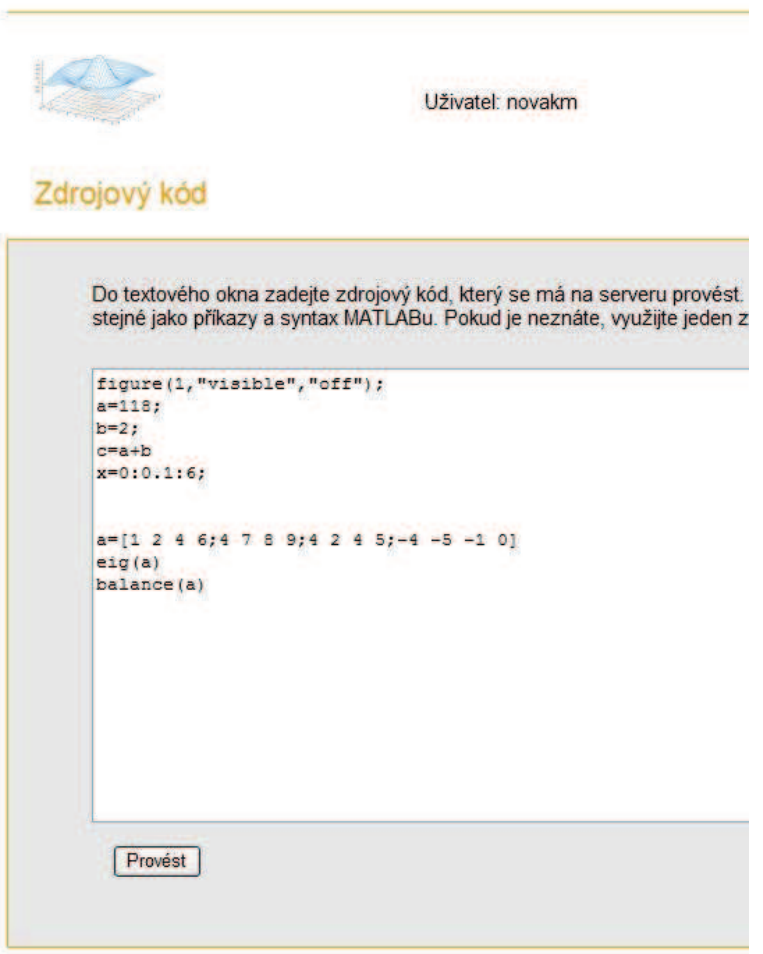

Výstup softwaru Octave

$c=120$

Fig. 1: Working with server installation of

Octave, an example. The white field is used for input, the button executes the commands, results are displayed in the gray field.

Maple web access is provided by MapleNET, a server installed technology. There are two ways MapleNET can be used for communication between client and the server: worksheets and maplets. Worksheets are native Maple files; MapleNET makes it possible to view their content in web browser. However, all interactivity is lost as on loading the webpage all commands are executed with preset parameters. With maplets, on the other hand, interactivity is preserved. In fact, maplets are applications which can be created using the standard version of Maple. They are worksheets with a handful of special commands with the source code visually not different from worksheets and exported in special maplet files with graphical user interface. The user thus cannot see their source code. However, all other aspects of work with Maple are preserved - this includes syntax of both input and output files as well as most of the standard Maple interactivity of output such as e.g. in 3D graphs. The difference between preparing Maple worksheets and maplets is thus only in preparing the GUI (a special graphical tool - Maplet Builder - can be used to facilitate this procedure) and incorporating rather intuitive commands for manipulating the GUI fields - for an example see Fig. 2. In the figure, notice that the menu enables the user to set properties of the graph, which are in worksheets accessible via the graph context menu. For more cf. e.g. (2).

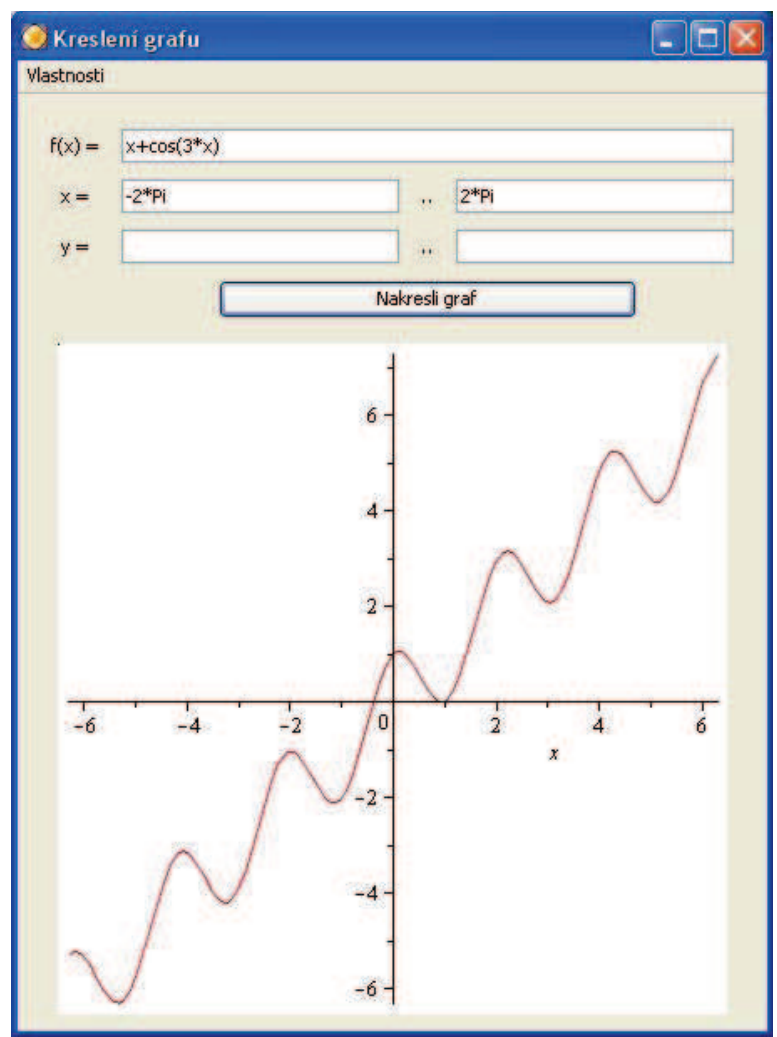

Fig. 2: Maplet, an example. This maplet will draw a function on a given range.

Maplets can be executed both on a computer where Maple is installed (from a directory) and thanks to MapleNET - on any computer with active internet connection (using a link on a web page). In both cases the files are identical.

Mathematica web access is provided by webMathematica, the philosophy of which is different from that of MapleNET. In webMathematica, interactive content is incorporated as an object into the webpage using special commands. This enables the content 
developer to include interactive mathematics as a part of a textual web page - see Fig. 3, where the slider provides interactivity. Upon moving it, the functions are redrawn.

\section{Grafy: základ logaritmu a exponenciálni funkce}

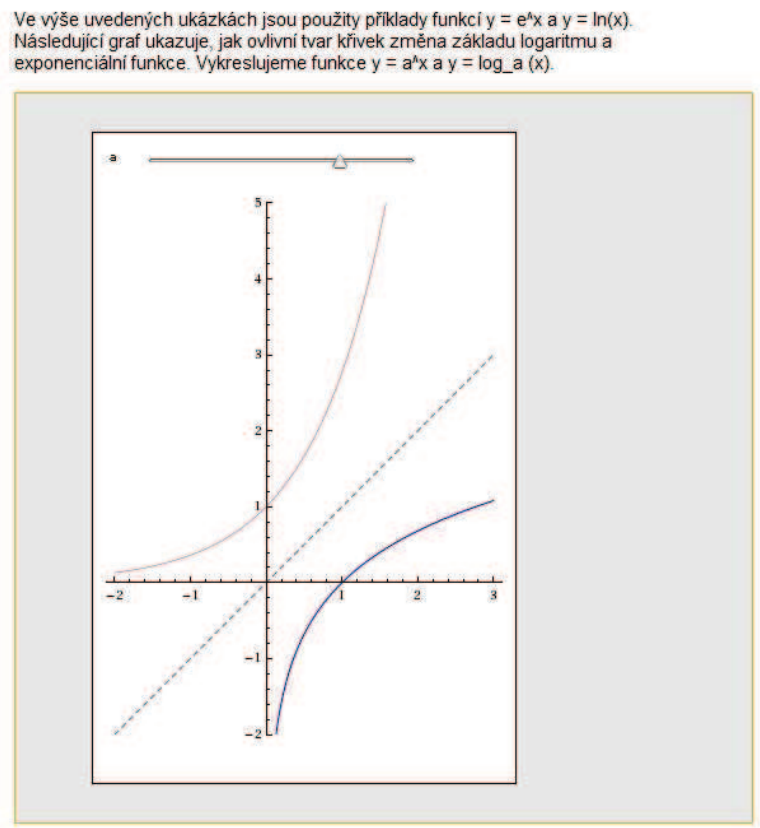

Fig. 3: Part of a web page with a webMathematica object. The object is used to

demonstrate the fact that logarithm and exponential are mutually inverse functions. The slider provides interactivity.

\section{Grafy: úlohy k samostatné pràci}

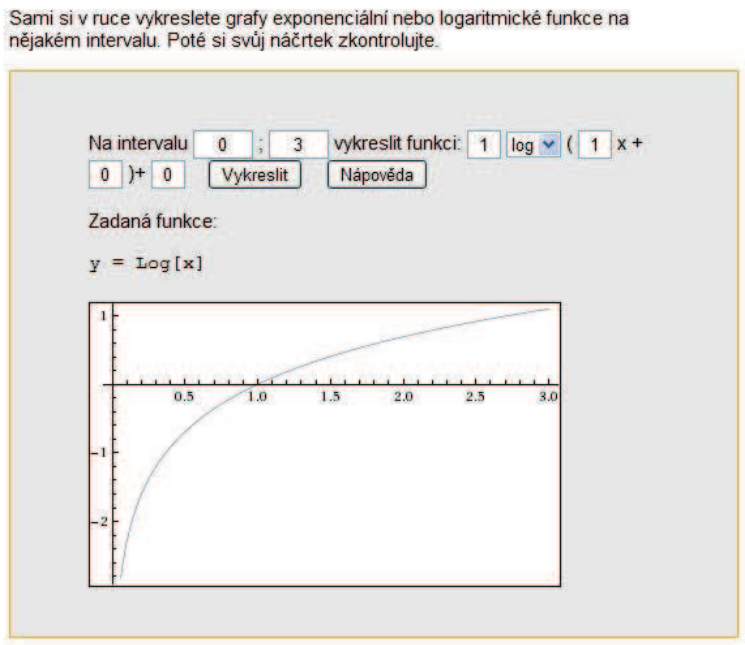

Fig. 4: Part of a web page with a webMathematica object. Initially, only the first two lines in the gray field are visible. The input specified in the text fields invokes output upon pressing the button on the left.

WebMathematica objects can be also used to display Mathematica output based on user input see Fig. 4.

MATLAB web access is not possible as MATLAB uses yet another approach to remote distribution. Like with Maple and its maplets, graphical user interface (GUI) applications can be prepared. However, they are not accessed in a server - client mode. Instead, the applications must be compiled by the distributor and distributed together with a special environment in which they can be executed. This environment (currently called MATLAB Compiler Runtime) is distributed free of charge. This effects the user as a requirement to use the distributed content implies the necessity to install software on a target computer, which might not always be possible for various reasons. The style of work is the same as with maplets; MATLAB GUI applications are visually similar to maplets.

\section{Teacher oriented tools}

Professional mathematical software can also be used as a tool for preparing and assessing tests on a large scale. Currently, this layer is possible with Maple only. Maple T.A. (1) enables users to prepare set of test questions of various types including parametric ones, create tests using these questions and assess such tests easily. Functionality of Maple is incorporated into the test questions and tests.

Since licensing schemes of Maple T.A. and complexity of the software make it suitable for universities rather than secondary schools, Maple T.A. and possible similar technologies shall not be discussed here.

\section{Other tools and technologies}

Apart from the above mentioned layers of Maple - MATLAB - Mathematica technologies, there exist also advanced professional modelling tools to each of the technology. However, these shall not be discussed here as their use in the secondary school context has not much sense.

It is to be noted that advanced mathematical content may also be distributed via the PDF format. Maple, Mathematica or MATLAB content (especially graphs and animations) can be inserted into PDF files using either Adobe solutions (such as Acrobat 9 Pro Extended) or a combination of third party technologies. For details cf. e.g. (Plch, Šarmanová, 2008) 
Interactivity of such content will be preserved in the PDF files.

\section{The technologies in teaching mathematics}

In parts $2-6$ the range of available technologies used in professional mathematical software was presented. In this section we would like to discuss how the technologies might be used in teaching mathematics at secondary schools in order help target students to overcome possible difficulties caused by a technological "jump" between their secondary education and first semesters of their engineering education. The importance of minimizing difficulties in this aspect is implied by growing amount of content and complexity of issues dealt with in both mathematical and engineering subject. This holds even for basic introductory courses of mathematics as at e.g. FEEC BUT theory of complex variable or integral transforms are taught in the second semester in the form of practical computer-aided classes (using Maple). Numerical methods are included in the third semester (again with computer-aided practical classes, now using MATLAB). Engineering subjects make use of professional software (including e.g. MATLAB) automatically. Naturally, a student familiar with the technologies at least to some extent is in a much better position than the one who has never encountered them.

Therefore, how can a teacher use the technologies in class to improve the class? How can a teacher use the technologies to help their students considering entering a university of technology?

Sources regarding the issue of using the standalone versions of mathematical software are rich. It is to be noted that is not important what specific software the respective sources discuss as the conclusions can definitely be generalized.

Using the web access, however, opens new horizons as the material used in classes need not be prepared by teachers of the institutions themselves. E.g. within the project mentioned in the introduction, Department of Mathematics FEEC BUT provides MapleNET and webMathematica content tailored to partner secondary schools on the request of the schools. This is a convenient mode of work for the schools as the most laborious and unpleasant work is done by someone else yet the schools have control over the result. Yet advantages for the Department are also obvious: target students will be familiar with the technologies used. At absolute minimum, they will know some of the syntax used by the software - and this is not unimportant as problems caused by not knowing correct syntax can be uncomfortable to such an extent that the user might reject using the software.

Using Octave the way mentioned in section 4 brings further advantages. The software can be used both in classes of mathematics (especially at advanced "good" schools) or in classes of informatics to teach thinking in algorithms (notice that MATLAB / Octave are used especially when numerical mathematics is needed - thus using algorithms is their native method of work). Knowing the philosophy and syntax of MATLAB is a bonus that students will appreciate when they decide for engineering type of their tertiary education.

Suggestion to use the GUI applications (maplets using MapleNET or MATLAB GUI applications) for homework or home practice is obvious. Even mere experimenting with such tools is helpful for students. This is especially true if the applications are prepared in a step-bystep way, i.e. if they display stages of solutions of the respective problem or - if the nature of the problem makes this possible - enable the user to choose different strategies in solving the task. In this case students can easily see implications of their wrong decisions and thus learn from their mistakes.

Combining the above technologies with hardware available in schools is another issue. Regardless of the software layer (stand-alone software, web access, etc.) or of the technology (Maple - Mathematica - MATLAB), using technologies such as interactive boards or their additional components can enhance the education even more. This is especially true when such hardware is used to display interactive content such as 3D plots or content suggested by Fig. 3 .

\section{Financial issues}

So far, use of a great number of technologies has been suggested. Naturally, if they are to be used, financial issues must be discussed. For details cf. pricelists on respective homepages $(1,3,6)$.

Pricing of stand-alone versions of Maple or Mathematica is reasonable. Both products are available in special educational / secondary school licensing schemes either as single-user licences or school-wide licences. Obtaining trial versions is possible. Under some special 
conditions Mathematica provides some users with an additional home-licence.

Buying MATLAB would not be of much use for a secondary school. However, using Octave brings the same effects free of charge. The software could be installed either on the school server or at any number of school / home computers.

Preparing maplets is only a little more timeconsuming than preparing standard Maple worksheets. Moreover, if an interactive board is available, the content can be distributed to students with a single Maple licence only via the teacher's computer (or even notebook, i.e. the computer using which the teacher could have prepared the content outside school). The same holds in this case for standard Maple worksheets or native Mathematica files.

Buying technologies for web access or buying teacher-oriented tools is possible most likely only with some additional funding as these cost hundreds thousands crowns. Co-operation with universities might be much more effective. Becoming a partner school of the project of Department of Mathematics FEEC BUT (5) is an example. Using free sources such as (2) is another option.

\section{Conclusions}

In the article we have given an overview of technologies commonly used at universities of technology, which a prospective engineer is likely to face immediately when he/she starts his/her tertiary education. His/her success may be influenced by the fact whether he/she had come into contact with these technologies at the secondary school. Even though the technologies are rather advanced, their use during secondary education may be very effective, meaningful and helpful and also affordable.

\section{References}

[1] Přrehled produktů. Praha: Czech Software First, $\quad$ s.r.o. URL: < http://www.maplesoft.cz/prehled-produktu>

[2] Maplets Archive. Lexington: University of Kentucky. URL: http://maplenet.msc.uky.edu/maplets/> [3] MATLAB, Simulink. Praha: Humusoft, s.r.o. URL:

http://www.humusoft.cz/produkty/matlab/>

[4] Mathematica. Praha: ELKAN, spol. s r.o. URL: < http://www.mathematica.cz/>
[5] Stránky projektu CZ.1.07/1.3.00/14.0001. Brno: VUT v Brně. URL: < http://matika.umat.feec.vutbr.cz/dvpp/>

[6] Wolfram webMathematica 3. Champaign (USA): Wolfram Research, Inc: URL: < http://www.wolfram.com/products/webmathemat ica/>

[7] HLAVIČKOVÁ, I. MATLAB. Electronic textbook for the educational programme Mathematics: how to motivate secondary school students to study at universities of technology. Brno: VUT v Brně, 2012. 51 pp. ISBN 978-80214-4481-2 (available also in Czech)

[8] KOLÁŘOVÁ, E. Maple. Electronic textbook for the educational programme Mathematics: how to motivate secondary school students to study at universities of technology. Brno: VUT v Brně, 2012. 48 pp. ISBN 978-80-214-4473-7 (available also in Czech)

[9] KOVÁR, M. Mathematica. Electronic textbook for the educational programme Mathematics: how to motivate secondary school students to study at universities of technology. Brno: VUT v Brně, 2012. 78 pp. ISBN 978-80214-4479-9 (available also in Czech)

[10] PLCH, R., ŠARMANOVÁ, P. An interactive Presentation of Maple 3D Graphics in PDF Documents. Electronic Journal of Mathematics and Technology. ISSN 1933-2823, 2008, vol. 2, no. 3, pp. 281-290.

[11] PLCH, R., ŠARMANOVÁ, P. Interaktivní 3D grafika v HTML a PDF dokumentech. Zpravodaj Československého sdružení uživatelì $T E X u$. Praha, Československé sdružení uživatelů TEXu. ISSN 1211-6661, 2008, vol. 18, no. 1-2, pp. 76-92

[12] VANÍČEK, J. Počitačové kognitivní technologie ve výuce geometrie. Praha: PdF UK, 2009. 213 pp. ISBN 978-80-7290-394-8.

[13] ŽILKOVÁ, K. Školská matematika v prostredi IKT. Bratislava: UK, 2009. 136 pp. ISBN 978-80-223-2555-4.

RNDr. Michal Novák, Ph.D.

Ústav matematiky

Fakulta elektrotechniky a komunikačních

technologií VUT v Brně

Technická 8

61600 , Brno, ČR

Tel: +420 541143135

E-mail: novakm@feec.vutbr.cz

Www pracoviště: www.umat.feec.vutbr.cz 